Review Article

\title{
MEDICINAL SIGNIFICANCE OF NOVEL COUMARINS: A REVIEW
}

\author{
SHARANABASAPPA B. PATIL", GOURAMMA P., SHIVAKUMAR S. JALDE
}

*Department of Chemistry, Ramaiah Institute of Technology, Bangalore 560054, Department of Chemistry, S B College of Science Kalaburagi 585102, Karnataka, India, Department of Medicinal Chemistry, Jungwon University Goesan 28024, Republic of Korea Email: sbp7910@gmail.com

Received: 02 May 2021, Revised and Accepted: 24 Jun 2021

\section{ABSTRACT}

Coumarone is a chemical compound found in many plants. Coumarone having diverse pharmacological properties popularly known as an antimicrobial, Analgesic anti-inflammatory, Anticancer, Antiviral, anticoagulant, antihypertensive, anticonvulsant, antihyperglycemic, antioxidant, activities. Coumarone was also observed in all green color veggies, and also in fruits and their seeds, dark coffee, tea leafs, further it is used for herbal remedies due to having less toxicity, very cheaper. The most useful method for the synthesis of Coumarone is from phenol and ethyl acetate and also by using catalyst. In this paper we tried to update the observations of authors towards the biological and medicinal significance of novel the natural and synthetic coumarone derivatives.

Keywords: Coumarone derivatives, Biological and Pharmacological activities

(C) 2021 The Authors. Published by Innovare Academic Sciences Pvt Ltd. This is an open access article under the CC BY license (https://creativecommons.org/licenses/by/4.0/) DOI: https://dx.doi.org/10.22159/ijcpr.2021v13i4.42733 Journal homepage: https://innovareacademics.in/journals/index.php/ijcpr

\section{INTRODUCTION}

Coumarone consists the huge class of phenolic compounds $[1,2]$ Coumarone were initially observed in Tonka bean and having thirty different families [3-9]. Coumarone also observed in some of the oils such as cassia oil [10], cinnamon oil [11-16] etc.<smiles>O=c1ccc2ccccc2o1</smiles>

Fig. 1: Coumarin or benzpyrone

As coumarin having the properties of blood thinning and antitumour properties, so it should not be taken while using anticoagulant. In view of these literature surveys, several natural and synthetic coumarin (2-oxo-2H-chromene) derivatives showed various medicinal and pharmacological activities [17-21]. Coumarins are also widely used as therapeutic agents and malignancies [22, 23].

\section{Medicinal applications}

Steffen et al. [24] synthesized hydroxycoumarin derivatives and screened on human tumor cells. Egan and his team [25, 26] was observed cytostatic and cytotoxic nature of nitro substituted hydroxycoumarin. Warfarin, a coumarin analog was more or less cytotoxic against tumor cells [27]. Warfarin was reported to inhibit rat mammary carcinoma<smiles>CC(=O)CC(c1ccccc1)c1c(O)c2ccccc2oc1=O</smiles>

Fig. 2: Warafarin

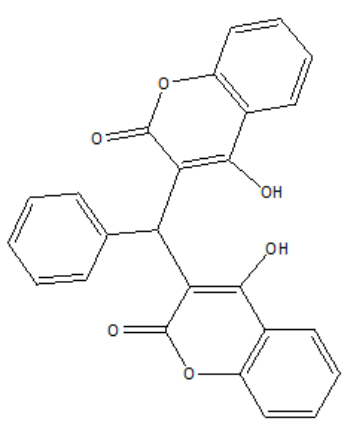

Fig. 3: 3,3'-Benzylidene-bis (4-hydrpxycoumanin)
The following coumarone complex derivatives showed good anticoagulant action.<smiles>O=c1oc2ccccc2c(O)c1S(=O)(=O)O</smiles>

Fig. 4: 3-Sulfo-4-hydroxycoumarin

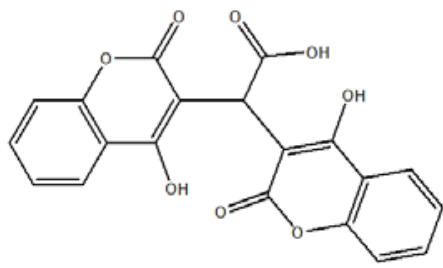

Fig. 5: Bis-(4hydroxy-3-coumarinyl)-acetic acid

Kerr et al. [31-37] synthesized compounds that inhibit the Vitamin K and Kam et al. [38] sythesisezed various isocoumarin derivatives.
Akmal and team $[28,29]$ observed synergistic cytotoxicity activity [30]. 
<smiles>N=C(S)NCCCOc1oc(=O)c2cc(N)ccc2c1Cl</smiles>

Fig. 6: 7-Amino-4-chloro-3-(3-isothioureidopropoxy) isocoumarin

Smirnova and team reported various coumanrone derivatives [39] Wallin et al. [40] and Hart et al. [40] have studied the synthesis and anticoagulant activity of coumarin derivatives. Yamada [42, 43] and team observed the spasmolytic activity of several coumarin compounds. Aminov and team [44]. Observed spasmolytic and hypotensive activities. Brhamabhatt et al. [45] have synthesized various derivatives. Bhosale et al. [46] have reported the synthesis and antipsychotic activity of new coumarinoacetamides.

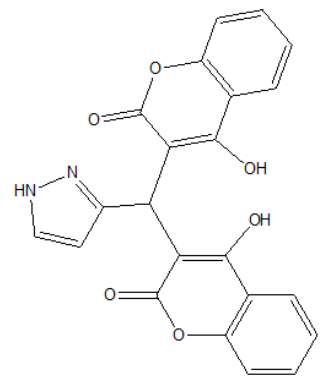

Fig. 7: Bis(4-hydroxy-2-oxo-2H-chromen-3-yl)-(1H-pyrazol-3yl)-methane

Irena $\mathrm{K}$ et al. [47] sythesised the various coumarin complexes. Recently, Antigoni Kotali et al.[48] observed the antileucemic activity of coumarin benzoylhyrozone derivatives.<smiles>CC(=O)c1c(O)ccc2ccc(=NNC(=O)c3ccccc3)oc12</smiles>

Fig. 8: 7- Hydroxy-8-acetylcoumarin benzoy 1hydrazone

Shingare et al. [49] have reported a new methodology for the synthesis of coumarinophosphorothioates from 7-hydroxy coumarin derivatives using 0 , 0 -diethyl phosphorochloridothiate in presence of sodium hydroxide and aliquat 336 as catalyst.

\section{Biological activities}

Desai et al. have mentioned ecofriendly microwave synthesis of imidazole derivatives containing coumarin moiety and their antimicrobial activity.

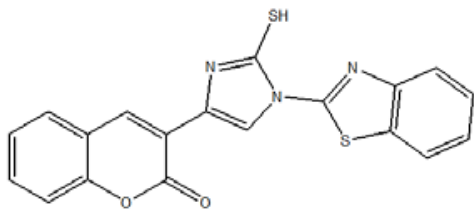

Fig. 9: 3-(1-(Benzo[d]thiazol-2-yl)-2-mercapto-1H-imidazol-4yl)-2H-benzpyra-2-one
Sandeep et al. [50, 51] observed significant antimicrobial and antiinflammatory activities.

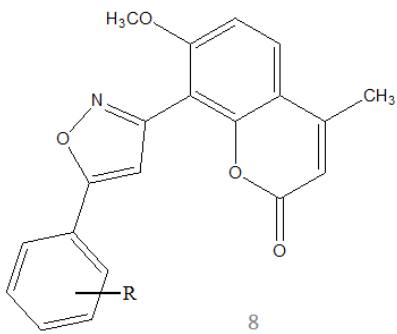

Fig. 10: 7Methoxy-4-methyl-8-[5-arylisoxazol-3-yl]-2H benzopyran-2-one

Rafat M. and team [52] observed antifungal and antibacterial activities.<smiles></smiles>

Fig. 11: 8-Methyl-9H-pyreno[1,2-6]pyran-9-one<smiles>Cc1cc2ccc3cc4ccccc4cc3c2oc1=O</smiles>

Fig. 12: 3-Methyl 2H-anthra[l,2-b]pyran-2-one

Novobiocin, Coumermycin and clorobiocin are potent antibiotics.<smiles>CC(C)=CCc1cc(C(=O)Nc2cc3ccc(OC4CC5(C)OC(OC(N)=O)(C4)O5)c(C)c3oc2=O)ccc1O</smiles>

Fig. 13: $\mathrm{R}=\mathrm{H}, \mathrm{Na}$<smiles>CC(C)=CCc1cc(C(=O)Nc2c(O)c3ccc(OC4CC5(OC(=O)c6ccc(C)[nH]6)OC(C)C(C)(C4)O5)c(Cl)c3oc2=O)ccc1O</smiles>

Fig. 14: Cloromycin 


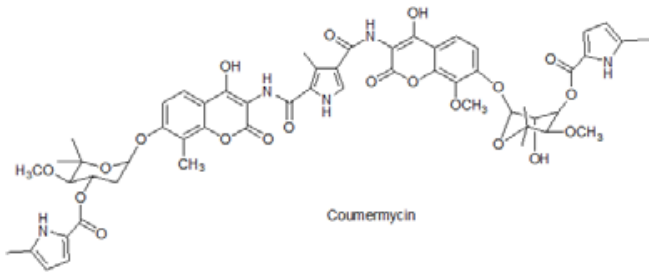

Fig. 15: Coumermycin

Coumarone derivatives showed strong coronary vasodilating activity.<smiles></smiles>

Fig. 16: 7-0xycoumarin skeleton

Recently, the Synthetic 7-hydroxy coumarone derivative observed as an antianginal drug.

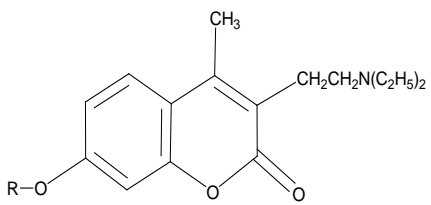

Fig. 17: 3ß-Diethylaminoethyl-4-methylcoumarin-7ethyloxyacetate

A number of naturally occurring as well as synthetic furocoumarins such as psoralen etc are well known for their dermal photosensiting estrogenic, antibacterial, antifungal, antiviral and insectisidal activities. Marked anti-fertility activity of a number of diphenyl furocoumarins is also attributed to a triaryl ethylene pattern.

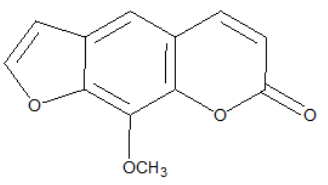

Fig. 18: 5-Methoxy psoralen<smiles>COc1c2ccoc2cc2oc(=O)ccc12</smiles>

Fig. 19: 8-Methoxy psoralen<smiles>COc1cc2cc3c(OC)cc(=O)oc3c(OC)c2o1</smiles>

Fig. 20: 4, 5',8-Trimethoxy psoralen
Various pyrano benzopyrans are known for their biological activities. Some pyrono benzopyran 2,5 diones are well known for their anticoagulant activity, CNS activity and anti-HIV agents.

Other known antioxidants include curcumin found in turmeric and ginger.

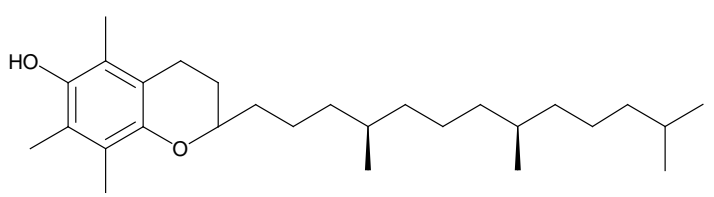

Fig. 21: $\alpha$-Tocophero

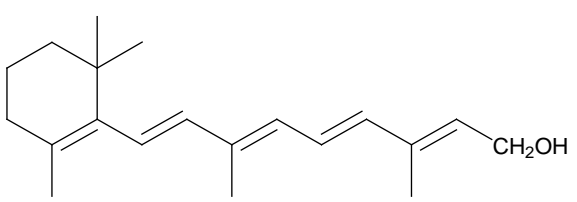

Fig. 22: Retinal<smiles>Cc1c(C)c2c(c(C)c1O)CCC(C)(C)O2</smiles>

Fig. 23: 2,2,5,7,8,-Pentamethyl-6-chromanol

The benzofurano (3,2-b) pyridines and tetra hydropyridines have been reported as potential anti-allergic agents and potential antidepressants.<smiles>O=c1oc2cc3c(cc2c2ccncc12)COC3</smiles>

Fig. 24: Thymine dimer photosensitiser

Pyridine-fused coumarins and benzofuran<smiles>[R]c1nc2c3ccccc3oc2c2c1c(=O)oc1ccccc12</smiles>

Fig. 25: Novel angularly fused pentacyclic heterocycles<smiles>[R]c1ccc2oc(=O)c([R])c([R])c2c1</smiles>

Fig. 26: Diversified coumarin 
3-carboxyl coumarin derivatives useful as GPR35 agonists observed by Liang, Xinmiao et al. and $\mathrm{Li}$, Xue was observed antiplatelet aggregation activity.

Derivaties of (coumarin-4-yl) aminocarboxylic acids, (thiocoumarin4-yl) aminocarboxylic acids and (2-oxo-1,2-dihydroquinolin-4-yl) aminocarboxylic acids (I) (R1 is a hydrogen or a nitro group; $\mathrm{X}$ is $\mathrm{O}, \mathrm{S}$ or $\mathrm{NH}$; $\mathrm{Y}$ is $\mathrm{OH}, \mathrm{OCH} 3, \mathrm{OC} 2 \mathrm{H} 5$, $\mathrm{NH} 2$ or $\mathrm{NHCH} 3 ; \mathrm{n}=3,4,5,6$ ) were showed as anticonvulsants observed by Mokrov, G. V

\section{Following Coumarone derivatives synthesized in our laboratory}

Naganna M. Goudgaon et al. [53] synthesized and observed antimicrobial activites of a series of some innovative substituted coumarone derivatives.

Sharanabasappa B. Patil et al. [54]., synthesized and observed antimicrobial activity of 6-bromo-3-((E)-3-(3-(Aryl)-1-phenyl-1Hpyrazol4-yl)acryloyl)-2H-chromen-2-ones, $\quad$ 6-bromo-3-(1,2,5,6tetrahydro-6-(3-(Aryl)-1-phenyl1H-pyrazol-4-yl)-2-thioxopyrimidin4-yl)-2Hchhromen-2-ones, 4-(6-bromo-2-oxo-2Hchromen-3-yl)-5, 6dihydro-6-(3-(Aryl)-1-phenyl1H-pyrazol-4-yl) pyrimidin-2(1H)-ones and 6-bromo-3-(4, 5-dihydro-5-(3-(Aryl)-1-phenyl-1H.

\section{CONCLUSION}

The natural and Synthetic Coumarone derivatives showed potent biological properties. (such as anti-inflammatory, anticoagulant, antimicrobial, antiviral, anticancer, antihypertensive, antitubercular, anticonvulsant, antiadipogenic, antihyperglycemic, antioxidant, and neuroprotective)

\section{FUNDING}

Nil

\section{AUTHORS CONTRIBUTIONS}

All the authors have contributed equally.

\section{CONFLICT OF INTERESTS}

Declared none

\section{REFERENCES}

1. Y Aoyama, T Katayama, M Yamamoto, H Tanaka, K Kon. A new antitumor antibiotic product, demethylchartreusin. Isolation and biological activities. J Antibiotics 1992;45:875-8.

2. M Iranshahi, M Askari, A Sahebkar, D Hadjipavlou Litina Evaluation of antioxidant, anti-inflammatory and lipoxygenase inhibitory activities of the prenylated coumarin umbelliprenin. DARU 2009;17:99-103.

3. WC Evans. Trease and evans pharmacognosy, Elsevier Ltd. $16^{\text {th }}$ edition; 2009.

4. JA Mead, JN Smith, RT Williams. Studies in detoxication. 71. The metabolism of hydroxycoumarins. Biochem J 1958;68:67-74.

5. C Spino, M Dodier, S Sotheeswaran. Anti-HIV coumarins from calophyllum seed oil. Bioorg Med Chem Lett 1998;8:3475-8.

6. S Rosselli, AM Maggio, N Faraone. The cytotoxic properties of natural coumarins isolated from roots of ferulago campestris (Apiaceae) and of synthetic ester derivatives of aegelinol. Nat Prod Commun 2009;4:1701-6.

7. Atta-ur-Rahman, M Shabbir, S Ziauddin Sultani, A Jabbar, MI Choudhary. Cinnamates and coumarins from the leaves of Murraya paniculata. Phytochemistry 1997;44:683-5.

8. J Cohen. Critical review of the toxicology of coumarin with special reference to interspecies differences in metabolism and hepatotoxic response and their significance to man. Food Cosmetics Toxicol 1979;17:277-89.

9. RW Fuller, HR Bokesch, KR Gustafson. HIV inhibitory coumarins from latex of the tropical rainforest tree calophyllum teysmannii var. inophylloide. Bioorganic Med Chem Lett 1994;4:1961-4.

10. J Choi, KT Lee, H Ka, WT Jung, HJ Jung, HJ Park. Constituents of the essential oil of the cinnamomum cassia stem bark and the biological properties. Arch Pharmacal Res 2001;24:418-23.

11. F Bourgaud, A Hehn, R Larbat. Biosynthesis of coumarins in plants: a major pathway still to be unravelled for cytochrome P450 enzymes. Phytochem Rev 2006;5:293-308.
12. D Bogdal. Coumarins: fast synthesis by Knoevenagel condensation under microwave irradiation. J Chem Res Synopses 1998;8:468-9.

13. BG Lake. Coumarin metabolism, toxicity and carcinogenicity: relevance for human risk assessment. Food Chem Toxicol 1999;37:423-53.

14. D Egan, R O'Kennedy, E Moran, D Cox, E Prosser, RD Thornes. The pharmacology, metabolism, analysis, and applications of coumarin and coumarin-related compounds. Drug Metab Rev 1990;22:503-29.

15. ME Marshall, JL Mohler, K Edmonds. An updated review of the clinical development of coumarin (1,2-benzopyrone) and 7 hydroxycoumarin. J Cancer Res Clin Oncol 1994;120:S39-S42.

16. RDH Murray. Naturally occuring plant coumarins. In: Progress in the Chemistry of Organic Natural Products, Springer, New York, NY, USA; 1997. p. 2-105.

17. Hudson JB, Towers GHN, Steve M, Dorling Peter R. Proc int symp poisonous plants 1993. Chem Abstr 1996;19:1209.

18. Marshall ME, Butler K, Cantrell J, Wiseman C, Mendelsohn L. Treatment of advanced malignant melanoma with coumarin and cimetidine: a pilot study. Cancer Chemother Pharmacol 1989;24:65.

19. Cox D, O'Kennedy R, Thornes RD. The rarity of liver toxicity in patients treated with coumarin (1,2-benzopyrone). Human Toxicol 1989;8:501.

20. Steffen US, Weber B, Siegers C. Synthesis of a diverse serise of phosphacoumarins with biological activities. Res Commun Mol Pathol Pharmacol 1998;99:193.

21. Cooke D, Fitzpatrick B, O' Kennedy R, McCormack T, Egan D. Coumarin: biochemical profile and recent developments; John Wiley and Sons: New York; NY, USA; 1997. p. 311-22.

22. Dongamanti Ashok, Bachi Reddy Vanaja, Mdderla Sarasija, B Vijaya Lakshmi. Microwave-assisted synthesis of substituted 4chloro-8-methyl-2--(1,3-diphenyl-1H-pyrazol-4-yl)-1,5-dioxa$2 \mathrm{H}-$ phenanthren-6--ones and their antimicrobial activity. J Serb Chem Soc 2017;82:117-25.

23. Kostova I, Raleva S, Genova P, Argirova R. Structure-activity relationships of synthetic coumarins as HIV-1 inhibitors. Bioinorg Chem 2006 https://doi.org/10.1155/BCA/2006/68274

24. Daniele Simoni, Riccardo Rondanin, Riccardo Baruchello, Michele Rizzi, Giuseppina Grisolia, Marco Eleopra, et al. Novel terphenyls and 3,5-diaryl isoxazole derivatives endowed with growth-supporting and antiapoptotic properties. J Med Chem 2008;51:4796-803.

25. Sardari S, Mori Y, Horita K, Micetich RG, Nishibe S, Daneshtalab $M$. Synthesis and antifungal activity of coumarins and angular furanocoumarins. Bioorg Med Chem 1999;7:1933-40.

26. Teotia MP, Rastogi DK, Malik WU. Stereochemical features vis-a-vis spectral data on some nickel(II) complexes of amino ligands viz. 3,3'-Diamino-4,4'-dihydroxy diphenyl sulphone and 8-amino-7hydroxy-4-methylcoumarin. Inorg Chim Acta 1973;7:339.

27. Issa M, Omar MM, Sabrah BA, Mohamed SK. Complexes of cerium (III), thorium (IV) and dioxouranium (II) with 8(arylazo)-7-hydroxy-4 methyl coumarin dyes. J Indian Chem Soc 1992;69:186

28. El-Ansary AL, Omar NMM. New lanthanide complexes of 4methyl-7-hydroxycoumarin and their pharmacological activity. Egypt J Chem 1988;31:511-20.

29. Kerr JS, Li HY, Wexler RS, Robinson AJ, Rob Inson CS, Boswell $\mathrm{GA}$, et al. The characterization of potent novel warfarin analogs. Thromb Res 1997;88:127-36.

30. Kam CM, Kerrigan JE, Plaskon RR, Duffy EJ, Lollar P, Suddath FL, et al. Mechanism-based isocoumarin inhibitors for blood coagulation serine proteases. Effect of the 7-substituent in 7-amino-4-chloro-3(isothioureidoalkoxy)isocoumarins on inhibitory and anticoagulant potency. J Med Chem 1994;37:1298-306.

31. Kam CM, Kerrigan JE, Plaskon RR, Duffy EJ, Lollar P, Suddath FL, et al. Mecha-nism-based isocoumarin inhibitors for blood coagulation serine proteases. Effect of the 7-substituent in 7-amino-4-chloro-3isothioureidoalkoxy)isocoumarins on inhibitory and anticoagulant potency. J Med Chem 1994;37:1298-306.

32. Yamada M, Okamoto H, Kikuzaki N Nakatani. Spasmolytic activity of aurapten analogs. Biosci Biotechnol Biochem 1997;61:740. 
33. Brahambhatt DL, Pandya VP, Patel CN, Patel MA. Synthesis of some 3-(4-styryl-6-aryl-pyridin-2-yl)-and 3-(6-styryl-4-arylpyridin-2-yl) coumarins. Indian J Chem 2005;44b:1863.

34. Kotali A, Lafazanis IS, Athanassios Papageorgiou, Eleni Chrysogelou, Theodoros Lialiaris, Zacharias Sinakos. Synthesis, characterization and antileucemic activity of 7-hydroxy-8acetylcoumarin benzoylhydrazone. Molbank 2008;M574:1-4.

35. DiGiovanni J, Cooper CS, Grover JL. (eds). Handbook of experiment al pharmacology, New York; 1990;94/11:159-22.

36. Wattenberg JLW, Lam LKT, Fladmoe A. V Inhibition of chemical carcinogen-induced neoplasia by coumarins and aangelicalactone. Cancer Res 1979;39:1651-4.

37. Nair RV, Fisher EP, Safe SH, Cortez C, Harvey RG, DiGiovanni J. Novel coumarins as potential anticarcinogenic agents. Carcinogenesis 1991;12:65-9.

38. Kampranis SC, Gormley NA, Tranter R, Orphanides G, Maxwell A. Probing the binding of coumarins and cyclothialidines to DNA gyrase. Biochemistry 1999;38:1967-76.

39. Roe SM, Podromou C, O'Brien R, Ladbury JE, Piper PW, Pearl LH. Structural basis for inhibition of the Hsp90 molecular chaperone by the antitumor antibiotics radicicol and geldanamycin. J Med Chem 1999;42:260-6.

40. Yu XM, Shen G, Neckers L, Blake H, Holzbeierlein J, Cronk B, et al. Hsp90 inhibitors identified from a library of novobiocin analogues. J Am Chem Soc 2005;127:12778-9.

41. Y Jacquot. Synthesis, structure, and estrogenic activity of 4amino-3-(2-methylbenzyl)coumarins on human breast carcinoma cells. Bioorg Med Chem 2007;15:2269.

42. RB Arora, CN Mathur. Relationship between structure and anticoagulant activity of coumarin derivatives. J Pharmacol 1963;20:29.

43. Lan Xie, Yasuo Takeuchi, L Mark Cosentino, Kuo Husing Lee, Anti-AIDS Agents. Synthesis and structure-activity relationships of $\left(3^{\prime} R, 4^{\prime} R\right)-(+)$-cis-khellactone derivatives as novel potent anti-HIV agents. J Med Chem 1999;42:2662.
44. Nakagawa Goto K, Nakamura S, Lee KH, Antitumor Agents. Syntheses and evaluation of dietary antioxidant-taxoid conjugates as novel cytotoxic agents. Biorg Med Chem Lett 2007;17:2894.

45. Moon YJ, Wang X, Morris ME. Dietary flavonoids: effects on xenobiotic and carcinogen metabolism. Toxicol In Vitro 2006;20:187-210.

46. Hoult JRS, Paya M. Pharmacological and biochemical actions of simple coumarins: natural products with therapeutic potential. Gen Pharm 1996;27:713.

47. Neichi T, Koshihara Y, Murota SI. Inhibitory effect of esculetin on 5-lipoxygenase and leukotriene biosynthesis. Biochem Biophys Acta 1983;753:130.

48. Fylaktakidou KC, Hadjipavlou Litina D, Litinas KE, Nicolaides DN Natural and synthetic coumarin derivatives with antiinflammatory/antioxidant activities. Curr Pharm Design 2004;10:3813

49. Nicolaides DN, Filaktakidou KC, Litinas KE, Hadjipavlou Litina DJ. Synthesis and biological evaluation of several coumarin-4carboxamidoxime and 3-(coumarin-4-yl)-1,2,4-oxadiazole derivatives. Eur J Med Chem 1998;33:715-24.

50. Nicolaide SDN, Fylaktakidou KC, Litinas KE. Hadjipavlou litina d. J Eur Heterocyclic Chem 1998;35:619.

51. Sumakanth M, Sukanya M, Sruthi K. Antibacterial activity of mannich bases of coumarins. Eur J Biomed Pharm Sci 2019;6:288-94.

52. Naik Mamata Devendra, Bodke Yadav D, M Vijay Kumar, BC Revanasiddappa. An efficient one-pot synthesis of coumarinamino acid derivatives as potential anti-inflammatory and antioxidant agents. Synth Commun 2020;50:1210-6.

53. Parameshwarappa G, Lingamani J, Sharanabasappa B Patil, Naganna M Goudgaon. Synthesis and anti-mirobial activity of thiazole substituted coumarins. Heterocycl Commun 2009;15:343-8.

54. Sharanabasappa B Patil, NM Goudgaon. Synthesis and antimicrobial activity of novel coumarone analogues. Int J Pharm Sci Res 2019;10:960-5. 